\title{
MONIEZIOSIS OF SOVIET MERINO SHEEP IN ASTRAKHAN REGION IN THE RUSSIAN FEDERATION
}

\author{
Mahmoud ABDELHAMID ${ }^{1,2}{ }^{\star 凶}$, Natalia ZAKHARINA ${ }^{1}$ and Nikolay PUDOVKIN1,3 \\ ${ }^{1}$ Faculty of Veterinary Medicine, Astrakhan State University, Astrakhan, 14056, Russia \\ 2Faculty of Veterinary Medicine, Aswan University, Aswan, 81528, Egypt \\ ${ }^{3}$ Faculty of Veterinary Medicine, Saratov State Agrarian University, Saratov, 410003, Russia \\ Email: mahmoud.ahmed2509@aswu.edu.eg ; (D) ORCiD: 0000-0003-1984-4185 \\ supporting Information
}

\begin{abstract}
In present study, the prevalence of monieziosis infections was determined in Soviet Merino sheep and risk factors associated therewith was identified in Astrakhan, a region of traditional development of sheep farming located in the south of the European part of Russia. One thousand five hundred Soviet Merino sheep, different in age and sex, from different districts in the Astrakhan region, were examined using the Fülleborn's technique for detection of eggs of genus Moniezia in fecal samples. Histological sections of gravid proglottids were stained for histological and Scanning Electron Microscopy (SEM) examination. It was found that monieziosis was recorded (26.46 \%) among the examined sheep. Moniezisois was found more prevalent in grazing female (41.52\%) and young sheep (35.61\%). The highest incidence of monieziosis in Soviet Merino sheep was found in spring (37.02\%). By histological and SEM examination, the gravid proglottids of genus Moniezia, showing several compartments inside it containing several eggs and the proglottids containing bilateral genital pores and craspedote.
\end{abstract}

Keywords: Astrakhan, Cestode, Fecal examination, Merino sheep, Monieziosis.

Abbreviations: SEM: Scanning Electron Microscopy; H\&E: hematoxylin and eosin.

\section{INTRODUCTION}

Sheep breeding leads in terms of variety of products and is a priority development branch of agriculture in the south of Russia. The Soviet Merino is a fine-wool sheep breed with a high yield of high-quality fleece and meat (Ciani et al., 2015). It is grown throughout Russia especially in the Astrakhan Region, southern Russia (Deniskova et al., 2018). Huge damage to livestock in Russia and other countries is caused by intestinal helminthiases, especially Anoplocephalatoses, which are widespread on the territory of Russia; in some regions of the country, the infection rate of animals reaches $60 \%-100 \%$ (Belova, 2011; Gorlov et al., 2016; Abdelhamid et al., 2021), and this health-problem decreases efficiency of animal production especially in small farm systems (Charlier et al., 2020).

Monieziosis is helminthiasis of domestic and many wild ruminants, caused by cestodes of the genus Moniezia of the family Anoplocephalidae, as a parasite in the small intestine (Diop et al., 2015; Jalajakshi et al., 2016; Shangaraev et al., 2018). Monieziosis caused by Moniezia expansa and Moniezia benedni belongs to the most frequently occurring pasture helminthes of ruminant with worldwide distribution (Guo, 2017). Monieziosis constitutes a major problem in sheep raising countries as it cause great economic damage (Thooyavan et al., 2018; Sharma et al., 2020; Alfatlawi et al., 2021). Infection of sheep with monieziosis causes many negative consequences, including a delay in the growth and development of young animals, a decrease in the productivity of adults (Abdelhamid et al., 2021), and with a high intensity of invasion, the animal mortality is often observed (Hakhbiev et al., 2020). In heavy infection with genus Moniezia, the intestine of sheep becomes solid mass by the parasite; this causes diarrhea and thriftiness. The infection leads to loss of meat production and the wool, and then death. In addition, the outbreaks of enterotoxaemia may occurred due to parasitism (Uzal and Songer, 2008).

Knowledge of the zonal features of the epizootology of invasive diseases and the life cycle of their pathogens is the most important condition for effective therapeutic and prophylactic antiparasitic measures (Shangaraev et al., 2018). The purpose of present research was to study the monieziosis infection rate, for the first time, in Soviet Merino sheep in the Astrakhan region, based on the results of the fecal samples study in relation to possible risk factors. Histological staining and Scanning Electron Microscopy (SEM) was used for illustration the internal morphology of the gravid proglottids and eggs of genus Moniezia. 


\section{MATERIALS AND METHODS}

Study population and sample collection

For monieziosis infection screening, a total of 1500 fresh fecal samples of Soviet Merino sheep of different age and sex from different districts and farms of the Astrakhan region, southern Russia, were collected from April 2019 to April 2020. Fecal samples were collected rectally and stored in sealed plastic bags at chilling temperature prior to transportation to the Department of Parasitology, Faculty of Veterinary Medicine, Astrakhan State University.

\section{Parasitological examination}

In the laboratory, the fecal samples in the containers were stirred with a glass rod, $1 \mathrm{~g}$ each, were weighed, and then analyzed using the Fülleborn's flotation technique (Gałęcki et al., 2015). The presence of genus Moniezia eggs was observed under the microscope.

\section{Staining identification and SEM Study}

The gravid proglottids of genus Moniezia were collected from feces of the studied Merino sheep and fixed in $10 \%$ neutral phosphate-buffered formalin and processed for histological examination and then stained with hematoxylin and eosin (H\&E). For SEM, gravid proglottids were placed into a small amount of saline buffer, and then were fixed overnight in cold $2.5 \%$ glutaraldehyde in a $0.1 \mathrm{M}$ sodium cacodylate buffer at $\mathrm{pH}$ 7.4. Then, they were dehydrated in a graded ethanol series and dried using $\mathrm{CO}_{2}$ in an Emitech $\mathrm{K} 850$ critical point dryer. After being mounted on metal stubs, specimens were coated with gold/palladium in a Quorum Technologies SC7640 sputter coater and examined with a JEOL JSM 5400 LV Scanning Electron Microscope 15-25 KV and photographed (Yildiz, 2007).

\section{Ethical regulation of the study}

The study was carried out in accordance with the standards of humane treatment of animals and is based on the EU directive (86/609/EEC) and the Helsinki Declaration. The samples were collected in accordance with ethical animal guidelines and regulations set by the animal care committee of the Faculty of Veterinary Medicine, Astrakhan State University, and were in accordance with the internationally accepted principles animal care and use.

\section{RESULTS}

The results in Table 1 showed that 397 (26.46 \%) of the Soviet Merino sheep's fecal samples were diagnosed positive for infection with monieziosis. The percentages of monieziosis infection according to the age of sheep were $35.61 \%$ and $\mathbf{2 2 . 1 2} \%$ in young and adult, respectively. The ovine moniezisois was found more prevalent in grazing female sheep $(41.52 \%)$ than grazing male sheep (13.85\%). The highest incidence of monieziosis in Merino sheep was found in spring (37.02\%), followed by autumn (30.28\%), summer (19.86 \%) and the lowest was noticed in winter (22.65\%).

The eggs of the genus Moniezia appear to be cuboid, containing a pear-shaped apparatus (Figure 1). The emergence of gravid proglottids of the genus Moniezia is spontaneously excreted in the faeces of sheep (Figure 2). Gravid proglottids of the genus Moniezia, histologically, show several compartments within them containing several eggs (Figure 3). Eggs of the genus Moniezia are hidden by a thick layer of subshell droplets and contain a pear-shaped apparatus and tiny hooks inside (Figure 4). On SEM examination, several eggs of the genus Moniezia accumulated within the gravid proglottids is shown in Figure 5, and proglottids containing bilateral genital pores and craspedot is presented in Figure 6.

Table 1 - Effect of age, sex and season on prevalence of monieziosis of infected Soviet Merino sheep in the Astrakhan region.

\begin{tabular}{|c|c|c|c|}
\hline Factor & No. examined & No. infected & $\%$ \\
\hline Prevalence & 1500 & 397 & 26.46 \\
\hline \multicolumn{4}{|l|}{ Age } \\
\hline Immature (<2 years) & 483 & 172 & 35.61 \\
\hline Mature (>2 years) & 1017 & 225 & 22.12 \\
\hline \multicolumn{4}{|l|}{ Sex } \\
\hline Male & 816 & 113 & 13.85 \\
\hline Female & 684 & 284 & 41.52 \\
\hline \multicolumn{4}{|l|}{ Season } \\
\hline Winter & 256 & 58 & 22.65 \\
\hline Summer & 584 & 116 & 19.86 \\
\hline Spring & 343 & 127 & 37.02 \\
\hline Autumn & 317 & 96 & 30.28 \\
\hline
\end{tabular}




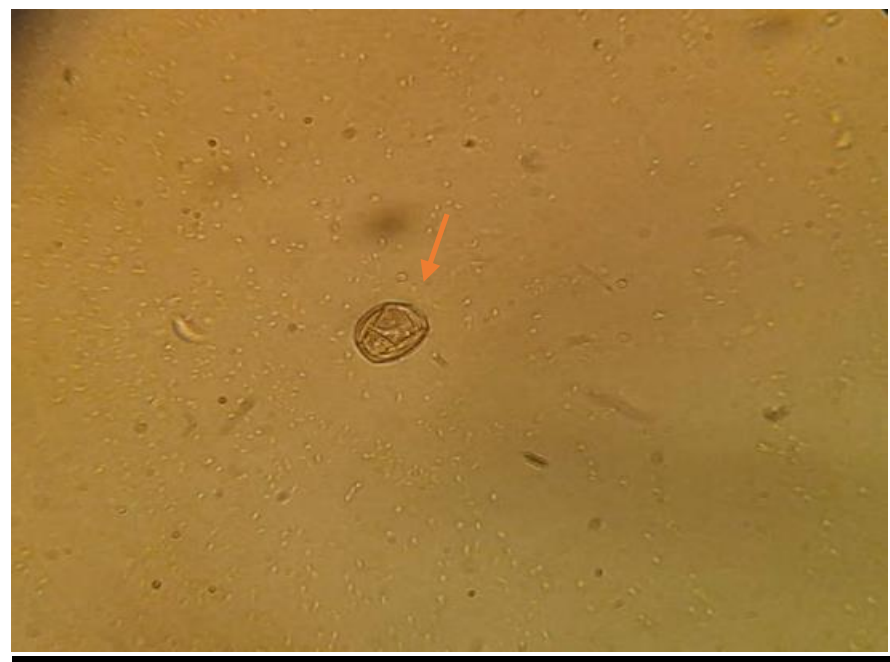

Figure 1 - A fecal sample containing an egg of the genus Moniezia.

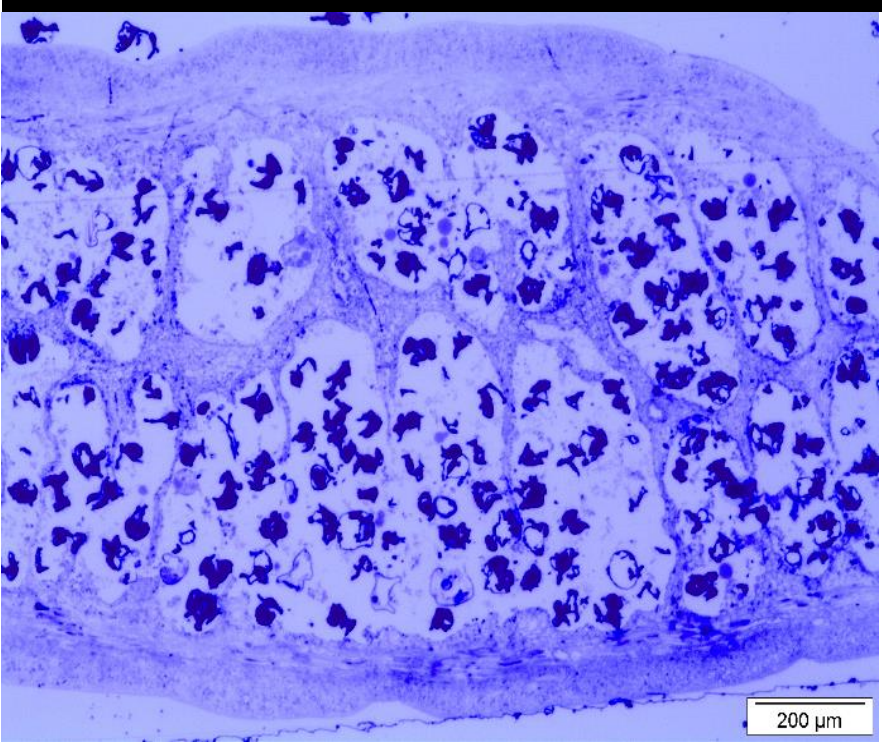

Figure 3 - Histological cross-section (H\&E stain) of a gravid proglottid of the genus Moniezia showing several compartments within it containing eggs.

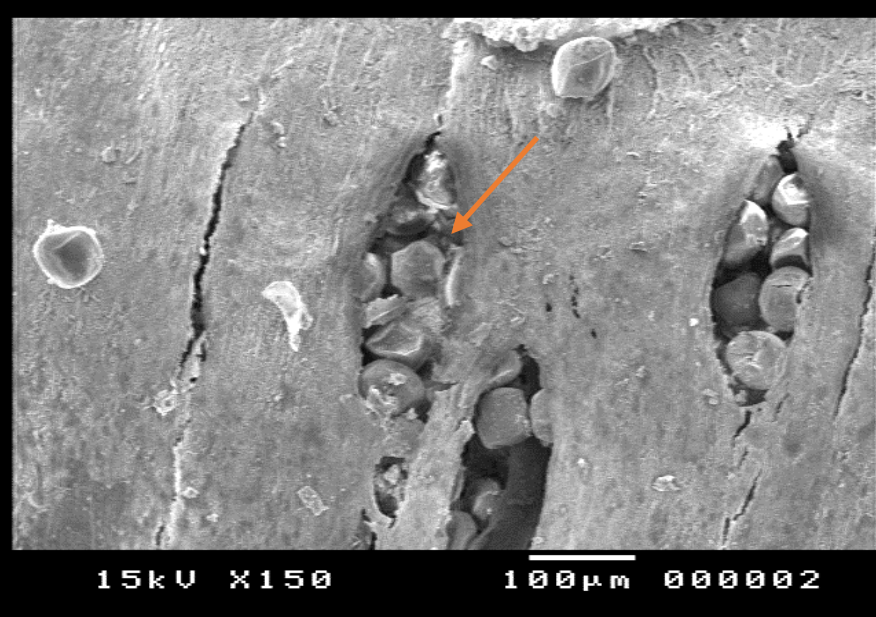

Figure 5 - Scanning electron microscopy of gravid proglottids of genus Moniezia, showing an accumulation of several eggs inside.

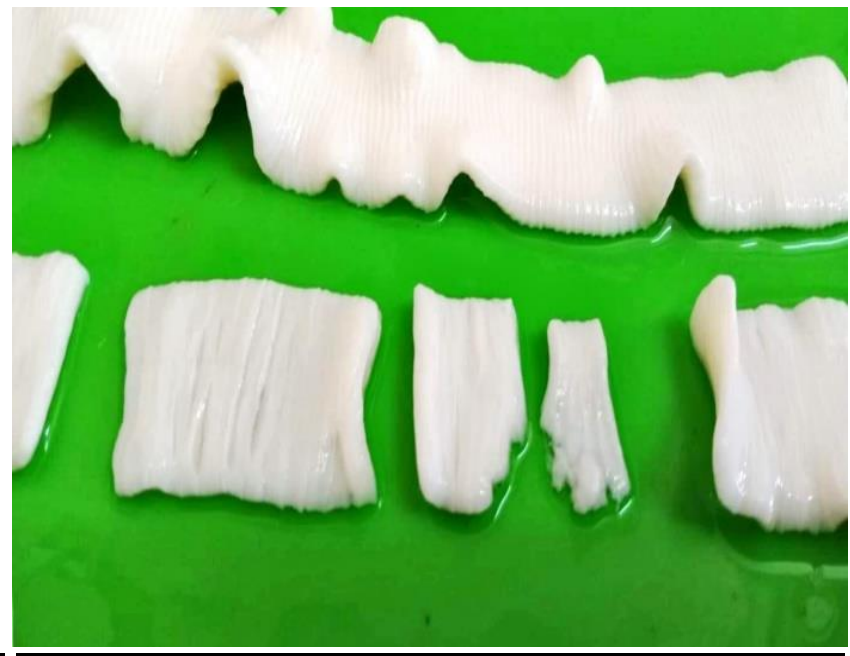

Figure 2 - The emergence of gravid proglottids of the genus Moniezia, which are spontaneously excreted in the faeces of sheep.

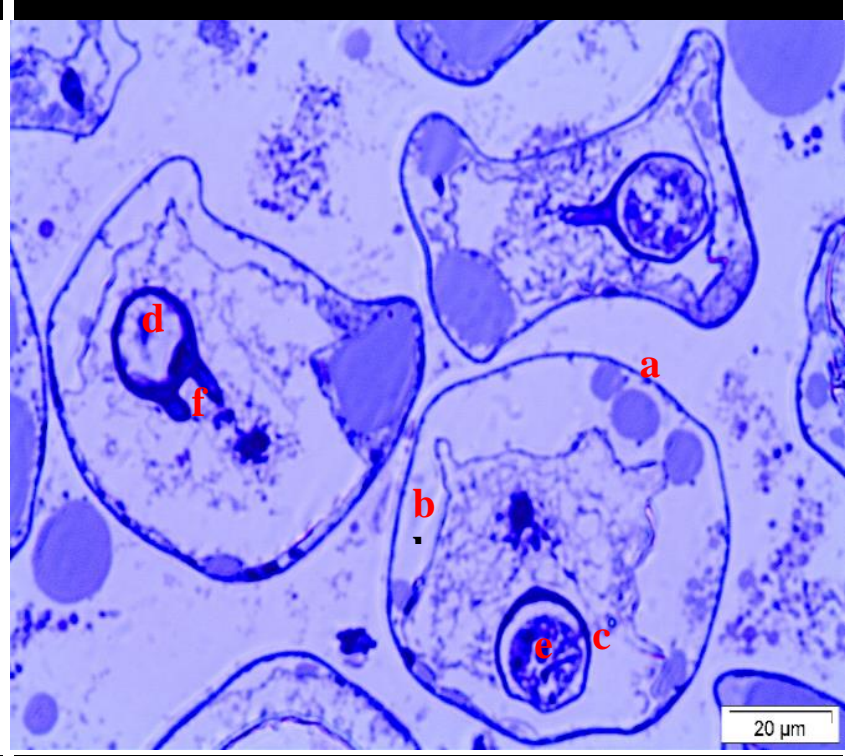

Figure 4 - Eggs of Moniezia spp: a. Eggshell, b. The intrathecal membrane, c. Onchospheric membrane, d. Onhocsphers, e. Hooks, f. Pear-shaped apparatus.

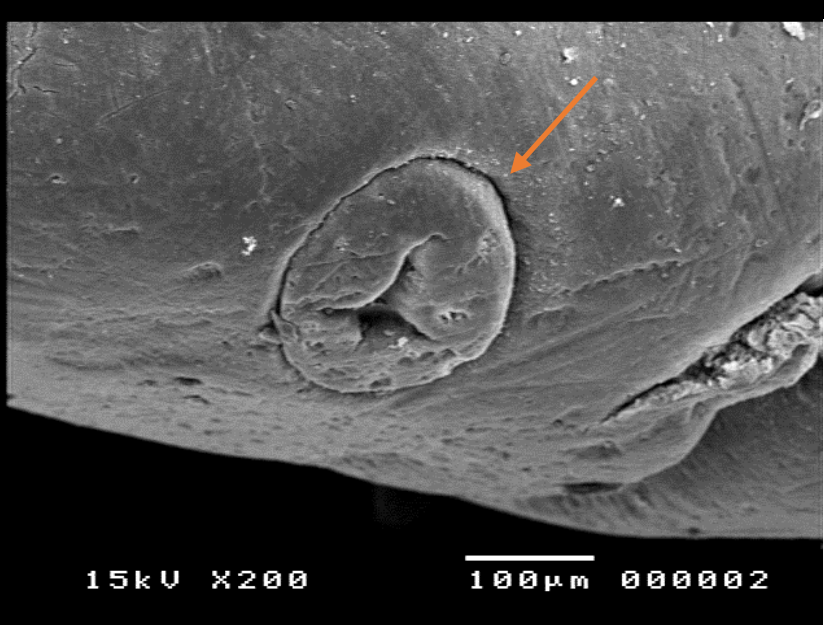

Figure 6 - SEM of gravid proglottids of genus Moniezia showing bilateral genital pores and craspedot. 


\section{DISCUSSION}

Monieziosis in sheep and goats could be considered as the most important parasitic diseases (Ismailov et al., 2011; Abdelhamid et al., 2021). The current study proved the detection of monieziosis infection, for the first time, in Soviet Merino sheep in the Astrakhan region with percentages reaching $26.46 \%$. This is close to the results of Belova (2011), who recorded the rate of occurrence of sheep monieziosis (29.84 \%) in Samara region, Southern Russia, as well as the results being consistent with those of Pavlović et al. (2017), who reported the rate of sheep monieziosis (26.77\%) in Vojvodina, Northern Serbia. Boyko et al. (2016) reported monieziosis of sheep (25.5\%) and (28\%) in Dnipropetrovsk and Odessa region of Ukraine, respectively. Present result was lower than that recorded by Shangaraev et al. (2018), who reported that small ruminants were infected with monieziosis by $\mathbf{5 2 . 7} \%$ in the Republic of Tatarstan, Shamkhalov et al. (2015) in Dagestan which was 68.7\%, and Memmedov (2009) $65.5 \%$ in Sherur Region of Azerbaijan. Bashtar et al. (2011) recorded a higher rate of sheep monieziosis (74\%) in Egypt, whereas present result was higher than that, Shah et al. (2018) reported with 3.49 \% in Kashmir, India. The prevalence variation of monieziosis infection in sheep between the prevalence in different studies may be attributed to change in the environmental factors, the type of rearing, regional differences, seasons, age, sex, hygiene; number of samples screened and control measures, where sheep raised on high protein diet developed resistance to parasitic gastroenteritis (Shamkhalov et al., 2015). In addition, the changes in climatic condition may affect the degree of infection. The present study reveals that monieziosis were $35.61 \%$ more prevalent in lamb. This result is in agreement with the study of Believ and Ataev, (2011), in the southeast of Northern Caucasus, who reported prevalence of genus Moniezia $66.7 \%$ and $21.6 \%$ for lamb and adult sheep, respectively. Similarly, Shamkhalov et al. (2015) reported $79.6 \%$ in lambs and $62.4 \%$ in adult animals. Lambs are more susceptible than adult to Monezia expansa infection and massive infection causes diarrhea and reduced weight gain (Elliott, 1986).Young animals are more vulnerable to intestinal parasites due their weaker immunological response. This can be linked to weaning stress, fat reserves or inadequate nutrition and low live weight (Hart, 2011). Older animals recover from parasitic infection more quickly as the immunity of the host increases with age. The adults might have also acquired immunity due to frequent exposure and there is tendency for them to expel the ingested parasites eggs infection (Alade and Bwala, 2015).

Present result showed that gender variation in the occurrence of sheep monieziosis. Prevalence of monieziosis was higher in ewe $(\mathbf{4 1 . 5 2} \%)$ than in ram (13.85\%). These findings were similar to that concluded by Dappawar et al. (2018). The higher prevalence in females was attributed to lowered resistance of female animals due to their reproductive events and insufficient/unbalanced diet against higher needs (Zvinorova, et al., 2016). Seasonal variation revealed highest prevalence of sheep monieziosis in spring (37.02 \%) followed by autumn (30.28\%), this in accordance with Ismailov et al. (2011).

Herbivorous animals become infected with monieziosis in the pasture when soil orbited mites, infected with cysticercoids, the larvae of genus Moniezia, enter the digestive tract with grass. The seasonal dynamics of sheep monieziosis correlates with the periods of activity of orbited mites (Shodmonov, 2017). The indicators of the population of pastures with orbited mites and their infestation with cysticercoid depend on climatic and weather conditions and the degree of infestation with monieziosis of grazed animals. The number of orbited mites on grazing decreases in winter and summer and increases in spring and autumn, which determines the timing of infection of sheep with monieziosis. A significant increase in the number of mites in the southern regions of Russia has been recorded (Nikitin et al., 2013).

\section{CONCLUSION}

Monieziosis was reported in this study, for the first time, in Soviet Merino sheep in Astrakhan region, Southern Russia. Monieziosis was recorded (26.46\%) among the examined sheep. Age, sex and season represent a risk factor for infection. The present study reveals that monieziosis were $35.61 \%$ more prevalent in lamb. The ovine moniezisois was found more prevalent in grazing female sheep (41.52\%) than grazing male sheep (13.85\%). The highest incidence of monieziosis in Merino sheep was found in spring (37.02\%), followed by autumn (30.28\%), and summer (19.86 \%), and the lowest was noticed in winter (22.65\%). By histological and SEM examination, the gravid proglottids of genus Moniezia, showing several compartments inside it containing several eggs and the proglottids containing bilateral genital pores and craspedote. Future studies are required to evaluate the parasitic dynamics and the impact on production on Soviet Merino sheep.

\section{DECLARATIONS}

\section{Corresponding author \\ E-mail: Mahmoud.ahmed2509@aswu.edu.eg}

\section{Authors' contribution}

Mahmoud Abdelhamid participated in the proposal design of the study, prepared the manuscript in writing and performed most of the laboratory analysis. Natalia Zakharina worked on reviewing and editing the proposal, recruitment 
of farmers into the study as well as contributed to laboratory analysis. Nikolay Pudovkin contributed to the final proposal design. All authors have read the manuscript before submitting for publication.

\section{Conflict of interests}

The authors have not declared any conflict of interests.

\section{Acknowledgement}

The authors thank to Astrakhan State University, Faculty of Veterinary Medicine for facilitating this research. The researcher Mahmoud Abdelhamid is funded by a scholarship under the joint (Executive Program between the Arab Republic of Egypt and Russia).

\section{REFERENCES}

Abdelhamid M, Vorobiev VI, Lapteva ML and Dyab AK (2021). Combined effect of monieziosis and hypomicroelementosis on some hematological, biochemical and hormonal parameters in Merino sheep. Pakistan Veterinary Journal, 41(1): $107-111$. DOI: http://www.doi.org/10.29261/pakvetj/2020.068

Alade NK and Bwala MD (2015). Gastrointestinal-parasites infestation in Yankasa sheep in a semi-arid environment. Livestock Research for Rural Development, 27: Article \#106. Link: http://www.Irrd.org/Irrd27/6/alad27106.html

Alfatlawi MA, Ismail YK, Ali MJ, Karawan AC and Ibadi IN (2021). Molecular differentiation of Thysaniezia (Helictometra) giardi and Moniezia species based on 18s rRNA gene in small ruminants. Iraqi Journal of Veterinary Sciences, 35(1): 105-108. DOI: http://www.doi.org/10.33899/ijvs.2020.126407.1313

Bashtar A, Hassanein M, Abdel-Ghaffar F, Al-Rasheid K, Hassan S, Mehlhorn H, AL-Mahdi M, Morsy K and Al-Ghamdi A (2011). Studies on monieziasis of sheep I. "Prevalence and anthelminthic effects of some plant extracts, a light and electron microscopic study. Parasitology Research, 108: 177-186. DOI: http://www.doi.org/10.1007/s00436-010-2060-2

Believ SM and Ataev AM (2011). Age features of infection of sheep by Moniezia spp. in the southeast of Northern Caucasus. $\begin{array}{llllll}\text { Russian Journal } & \text { of } & \text { Parasitology, } & 121 & (4): & 64-66 .\end{array}$ https://vniigis.ru/1_dlya_failov/RPJ/Arhiv/Russian_Journal_of_Parasitology_2011_4.pdf

Belova EE (2011). Distribution of anoplocephalatosis of sheep in Samara region in view of zone features. Russian Journal of Parasitology, 43(2): 50-53. 53\%20\%D0\%A0\%D0\%9F\%D0\%96_2011(1)-vniigis_ru.pdf

Boyko 00, Zazharska NM and Brygadyrenko VV (2016). The influence of the extent of infestation by helminths upon changes in body weight of sheep in Ukraine. Biosystems Diversity, 24(1): 3-7. DOI: http://www.doi.org/10.15421/011601

Charlier J, Rinaldi L, Musella V, Ploeger HW, Chartier C, Vineer HR, and Claerebout E (2020). Initial assessment of the economic burden of major parasitic helminth infections to the ruminant livestock industry in Europe. Preventive Veterinary Medicine, 182: 105103. DOI: https://doi.org/10.1016/j.prevetmed.2020.105103

Ciani E, Lasagna E, D'andrea M, Alloggio I, Marroni F, Ceccobelli S, and Pilla F (2015). Merino and Merino-derived sheep breeds: a genome-wide intercontinental study. Genetics Selection Evolution, 47(1): 1-12. DOI: https://doi.org/10.1186/s12711-015$\underline{0139-z}$

Dappawar MK, Khillare BS, Narladkar BW and Bhangale GN (2018). Prevalence of gastrointestinal parasites in small ruminants in Udgir area of Marathwada. Journal of Entomology and Zoology Studies, 6(4): 672-676. https://www.entomoljournal.com/archives/2018/vol6issue4/PartL/6-3-147-702.pdf

Deniskova TE, Dotsev AV, Selionova I, Kunz E, Medugorac I, Reyer H, and Zinovieva NA (2018). Population structure and genetic diversity of 25 Russian sheep breeds based on whole-genome genotyping. Genetics Selection Evolution, 50(1): 1-16. DOI: https://doi.org/10.1186/s12711-018-0399-5

Diop G, Yanagida T, Hailemariam Z, Menkir S, Nakao M, Sako Y, Ba CT and Ito A (2015). Genetic characterization of Moniezia species in Senegal and Ethiopia. Parasitology International, 64(5): 256-260. DOI: http://www.doi.org/10.1016/j.parint.2015.02.008

Elliott DC (1986). Tapeworm (Moniezia expansa) and its effect on sheep production: the evidence reviewed. New Zealand Veterinary Journal, 34(5): 61-65. DOI: http://www.doi.org/10.1080/00480169.1986.35289

Gałęcki R, Sokół R and Koziatek S (2015). Parasites of wild animals as a potential source of hazard to humans. Annals of Parasitology, 61: 105-108. Link: http://yadda.icm.edu.pl/yadda/element/bwmeta1.element.agro-62f6978e-0386-411f91d3-e30b3b49357a

Gorlov IF, Shirokova NV, Randelin AV, Voronkova VN, Mosolova NI, Zlobina EY, Kolosov YA, Bakoev NF, Leonova MA, Bakoev SY, Kolosov AY and Getmantseva LV (2016). CAST/Mspl gene polymorphism and its impact on growth traits of Soviet Merino and Salsk sheep breeds in the South European part of Russia. Turkish Journal of Veterinary and Animal Sciences, 40: 399405. DOI: http://www.doi.org/10.3906/vet-1507-101

Guo A (2017). Moniezia benedeni and Moniezia expansa are distinct cestode species based on complete mitochondrial genomes. Acta Tropica, 166: 287-292. DOI: http://www.doi.org/10.1016/j.actatropica.2016.11.032

Hakhbiev KK, Kosyaev NI and Hakhbiev IK (2020). Epizootological course of monieziosis of small cattle in the lowland regions of the Chechen republic. International Journal of Veterinary Medicine, 2020(1): 33-36. Link: https://vetjournal.spbguvm.ru/jour/article/view/145/146

Hart BL (2011). Behavioral defenses in animals against pathogens and parasites: parallels with the pillars of medicine in humans. Philosophical Transactions of the Royal Society B: Biological Sciences, 366 (1583): 3406-3417. D0I: http://www.doi.org/10.1098/rstb.2011.0092 
Ismailov GD, Fataliev GG, Azizova AA and Rzayev NM (2011). Ecologo-geographical analysis of distribution of monieziosis agents (Moniezia expansa, M. benedeni, M. autumnalia-cestoda, anoplocephalata) of the ruminant animals of Azerbaijan and their seasonal and age dynamics. South of Russia: Ecology, Development, 6(4): 219-223. DOI: http://www.doi.org/10.18470/1992-1098-2011-4-219-223

Jalajakshi K, Saritha G and Haritha GS (2016). Tape worm infestation in a sheep flock and control measures - case study. International Journal of Recent Scientific Research, $7(10)$ : 14096-14098. https://recentscientific.com/sites/default/files/6372.pdf

Memmedov E (2009). Prevalance of Moniezia Species in Sheep of Sherur Region of Nakhchivan Autonomous Republic. Kafkas Üniversitesi Veteriner Fakültesi Dergisi, 15(3): 465-467. DOI: http://www.doi.org/10.9775/kvfd.2009.046-A

Nikitin VF, Dudka NS, Lemekhov PA and Plyako AV (2013). Estimation of pastures on the presence of Oribatidae population and their infection by Moniezia spp. larva. Russian Journal of Parasitology, 41(2): 25-28. https://vniigis.elpub.ru/jour/article/view/30

Pavlović I, Becskei Z, Ivanović S, Petrović MP, Savić M, Caro-Petrović V and Bojkovski J (2017). Biodiversity of Helminths of Sheep Breed in Vojvodina (Northern Serbia). Bulletin UASVM Veterinary Medicine, 74(2): 162-166. DOI: http://www.doi.org/10.15835/buasvmen-vm:0011

Shah MM, Maqbool I, Manzoor A, Shabnum N, Rather T and Ahanger SA (2018). Seasonal prevalence of gastrointestinal parasites in sheep of Kashmir valley. Journal of Entomology and Zoology Studies, 6(6): 534-536. https://www.entomoljournal.com/archives/2018/vol6issue6/Partl/6-5-279-731.pdf

Shamkhalov VM, Magomedov OA, Shamkhalov MV, Gyulakhmedova NK and Bakrieva RM (2015). Distribution of intestinal helminthosis of sheep in Dagestan. Russian Journal of Parasitology, 41: 61-64. DOI: http://www.doi.org/10.15421/011601

Shangaraev RI, Lutfullin M K and Lutfullina NA (2018). Parasitoses of ruminants in personal farms of the Vysokogorsky and Laishevsky regions of the Republic of Tatarstan. Russian Journal of Parasitology, 12(3): 18-22. DOI: http://www.doi.org/10.31016/1998-8435-2018-12-3-18-22

Sharma DK, Paul S and Gururaj K (2020). Gastrointestinal Helminthic Challenges in Sheep and Goats in Afro-Asian Region: A Review. Journal of Animal Research, 10(1):1-18. DOI: http://www.doi.org/10.30954/2277-940X.01.2020.1

Shodmonov IS (2017). Features of epizootic process of monieziasis and mixed helminthiasis in sheep of the Republic of Tajikistan. Russian Journal of Parasitology, 42: 368-371. https://vniigis.elpub.ru/jour/article/view/438?locale=en_US

Thooyavan G, Kathikeyan J and Govindarajalu B (2018). Anthelmintic activity of Abutilon indicum leaf extract on sheep tapeworm Moniezia expansa in vitro. Journal of Pharmacognosy and Phytochemistry, 7(2): 317-321. https://www.phytojournal.com/archives/2018/vol7issue2/PartE/7-1-71-369.pdf

Uzal FA and Songer JF (2008). Diagnosis of Clostridium perfringens intestinal infections in sheep and goats. Journal of Veterinary Diagnostic Investigation, 20: 253-265. DOI: http://www.doi.org/10.1177/104063870802000301

Yildiz K (2007). The Scanning Electron Microscopic Examination of Avitellina centripunctata and Thysaniezia ovilla. Türkiye Parazitoloji Dergisi, 31(4): 292-295. Link: https://europepmc.org/article/med/18224619

Zvinorova PI, Halimani TE, Muchadeyi FC, Matika O, Riggio V and Dzamaa K (2016). Prevalence and risk factors of gastrointestinal parasitic infections in goats in low-input low-output farming systems in Zimbabwe. Small Ruminant Research, 143: 75-83. D0I: https://doi.org/10.1016/i.smallrumres.2016.09.005 